\title{
An Examination of Training Issues Associated with the Virtual Training Program
}

\author{
Theodore M. Shlechter \\ U.S. Army Research Institute \\ Scott B. Shadrick \\ Western Kentucky University \\ Consortium Research Fellows Program \\ David W. Bessemer \\ U.S. Army Research Institute \\ James Anthony \\ University of Louisville \\ Consortium Research Fellows Program

\section{Armored Forces Research Unit Barbara A. Black, Chief}
U.S. Army Research Institute for the Behavioral and Social Sciences 5001 Eisenhower Avenue, Alexandria, Virginia 22333-5600
Office, Deputy Chief of Staff for Personnel
Department of the Army

\section{September 1997}

